\title{
Spinal mobility in children with diabetes and factors, which influence it
}

\author{
O. Ye. Pashkova*A,E,F, K. P. Lysenko ${ }^{B-D}$
}

Zaporizhzhia State Medical University, Ukraine

A - research concept and design; B - collection and/or assembly of data; C - data analysis and interpretation; D - writing the article; $\mathrm{E}$ - critical revision of the article; $\mathrm{F}$ - final approval of the article

Key words: children, diabetes mellitus, periostin, vitamin D, spine mobility.

Pathologia 2020; 17 (1), 86-92

*E-mail: elenapashkova0901@ gmail.com
Aim of study: to evaluate spine mobility, as an integral marker of joint mobility, according to the duration of the disease and provision of vitamin $\mathrm{D}$ in children with diabetes.

Materials and research methods. Overall, 93 children from 11 to 17 years old with insulin-dependent diabetes were examined. According to the duration of the disease, all the children were divided into three groups: the first group consists of 26 children (average age $12.9 \pm 0.4$ years) with the duration of the disease less than a year, the second group consists of 33 patients (average age $13.8 \pm 0.4$ years) with the duration of the disease from one to five years, the third group consists of 34 patients (average age $14.3 \pm 0.4$ years) with the duration of the disease for more than five years. The control group consists of 30 conditionally healthy children that are representative by age and gender. Evaluation of joints motion was performed in all the children with the help of metrical tests. The content of vitamin $D$ and periostin was identified in blood serum by the method of immunoenzyme assay.

Results. It was found that in children with diabetes mellitus, compared with the control group, there is a decrease in spine mobility. Starting from the second year of disease, it was noticed that there is gradual decrease of mobility of all parts of the spine. We observed a decrease in blood serum vitamin $D$ levels, which progress with the enlargement of illness duration. In the first year of the disease, vitamin deficiency was only $10 \%$. At that time, in group 2 in $50 \%$ of children, and in group 3 in $80 \%$ of children there was a decrease in vitamin $D$ level $(P<0.05)$. Lack of vitamin $D$ sufficiency was accompanied by a deterioration of the overall mobility of the spine. The lowest levels of vitamin D were found in children with high-risk glycemic control.

It was determined that the level of periostin tended to increase gradually with the progress of diabetes. Data analysis showed that children with high levels of periostin had low levels vitamin D in blood serum.

Conclusions. Children with diabetes are characterized by the deterioration in the functional state of the spine in the form of reduced mobility in all its regions, which progress with an increase in the duration of the disease. One of the mechanisms for the development of the revealed violations is poor compensation for diabetes and vitamin $D$ deficiency.

Киючові слова: Аіти, цукровий Аіабет, періостин, вітамін D, рухиивість хребта.

\section{Стан рухиивості хребта в дітей, які хворі на цукровий діабет, та фактори, що на нього впливають}

\section{О. Є. Пашкова, К. П. Аисенко}

Мета роботи - оцінити стан рухливості хребта як інтегральний маркер стану суглобів у дітей, які хворі на цукровий діабет, залежно від тривалості перебігу захворювання та забезпеченості вітаміном D.

Патологія. 2020.

T. 17, № 1(48).

C. 86-92
Матеріали та методи. Обстежили 93 дитини, які хворі на інсулінозалежний діабет, віком від 11 до 17 років. Обстежених поділили 3 групи: 1 - 26 дітей (середній вік - 12,9 £ 0,4 року) з тривалістю цукрового діабету (ЦД) до 1 року; 2 - 33 пацієнти (середній вік - 13,8 \pm 0,4 року) з тривалістю захворювання від 1 до 5 років; 3 - 34 хворих (середній вік $14,3 \pm 0,4$ року) з тривалістю цукрового діабету понад 5 років. У контрольну групу ввійшли 30 умовно здорових дітей, репрезентативних за віком і статтю. Усім дітям виконали дослідження функціонального стану хребта за допомогою метричних тестів, визначили рівень вітаміну D і періостину за допомогою імуноферментного аналізу.

Результати. Встановили, що для дітей, які хворі на цукровий діабет, порівняно з контрольною групою притаманне зниження рухливості хребта. Перші ознаки цих змін виявляли вже з другого року захворювання, вони прогресували зі збільшенням тривалості перебігу цукрового діабету.

Встановлено, що з прогресуванням захворювання відбувалося поступове погіршення забезпеченістю вітаміном D. Якщо на першому році захворювання недостатність вітаміну визначена тільки в $10 \%$, у 2 групі - в 50 \% дітей, то при перебігу ЦД понад 5 років десріцит вітаміну D діагностували у $80 \%$ дітей $(p<0,05)$. Недостатній рівень забезпеченості вітаміном D супроводжувався погіршенням стану загальної рухливості хребта. Найнижчі значення рівня вітаміну $D$ притаманні дітям із глікемічним контролем із високим ризиком для життя $(r=-0,41, p<0,05)$.

Визначили, що рівень періостину мав тенденцію до поступового збільшення при прогресуванні цукрового діабету. Аналіз даних показав, що найбільший вміст періостину спостерігали у дітей з низькою забезпеченістю вітаміном $D$ y сироватці крові $(r=-0,36 ; p<0,05)$.

Висновки. Дітям, які хворі на цукровий діабет, притаманне погіршення функціонального стану хребта - зниження рухливості в усіх його відділах, що прогресують зі збільшенням тривалості захворювання. Одними з механізмів розвитку виявлених порушень $є$ незадовільна компенсація діабету та недостатня забезпеченість вітаміном D. 


\section{Состояние подвижности позвоночника у детей, больных сахарным диабетом, и факторы, которые на него влияют}

\section{Е. Е. Пашкова, К. П. Аысенко}

Цель работы - оценить состояние подвижности позвоночника как интегральный маркер состояния суставов у детей, больных сахарным диабетом, в зависимости от длительности течения заболевания и обеспеченности витамином D.

Материалы и методы. Обследовали 93 ребенка, больных инсулинозависимым диабетом, в возрасте от 11 до 17 лет, которых поделили на 3 группы: 1 - 26 детей (средний возраст - 12,9 \pm 0,4 года) с длительностью сахарного диабета (СД) до 1 года; 2 - 33 пациента (средний возраст - 13,8 \pm 0,4 года) с длительностью заболевания от 1 года до 5 лет; 3 - 34 больных (средний возраст - 14,3 \pm 0,4 года) с длительностью сахарного диабета более 5 лет. Контрольную группу составили 30 условно здоровых детей, репрезентативных по возрасту и полу. Всем детям проведено исследование функционального состояния позвоночника с помощью метрических тестов, определили уровень витамина D и периостина с помощью иммуноферментного анализа.

Результаты. Установлено, что для детей, больных сахарным диабетом, по сравнению с контрольной группой, характерно снижение подвижности позвоночника, первые признаки этих изменений определяли уже со второго года заболевания, они прогрессировали с увеличением длительности течения сахарного диабета.

Установлено, что с прогрессированием заболевания происходило постепенное ухудшение обеспеченности витамином D. Если на первом году заболевания недостаточность витамина D определена только у $10 \%$, во 2 группе - у $50 \%$ детей, то при течении СД более 5 лет десицит витамина D диагностирован у $80 \%$ детей $(p<0,05)$. Недостаточный уровень обеспеченности витамином $D$ сопровождался ухудшением состояния общей подвижности позвоночника. Самые низкие значения уровня витамина D присущи детям с гликемическим контролем с высоким риском для жизни $(r=-0,41 ; p<0,05)$.

Определено, что уровень периостина имел тенденцию к постепенному увеличению при прогрессировании сахарного диабета. Анализ данных показал, что наибольшее содержание периостина наблюдали у детей с низкой обеспеченностью витамином $D$ в сыворотке крови $(r=-0,36, p<0,05)$.

Выводы. Для детей, больных сахарным диабетом, характерно ухудшение функционального состояния позвоночникаснижение подвижности во всех его отделах, прогрессирующее с увеличением продолжительности заболевания. Одни из механизмов развития установленных нарушений - неудовлетворительная компенсация диабета и недостаточная обеспеченность витамином D.

There are more than 20 million people on the Earth with insulin-dependent diabetes, which is $10-15 \%$ of all patients with diabetes. Nevertheless, WHO experts prognose that the number of this patients will increase by 1.5 times until 2030 taking into consideration fast pace of this disease increase. The most important problem of insulin-dependent diabetes is revealing of early and late complications of different organs and systems, that cause worsening of life quality. The main reason for late complications is hyperglycemia [1]. That is why it is very important to treat diabetes correctly and on time. If during treatment it is not possible to achieve normoglycemia, this leads to chronic complications, such as diabetic retinopathy, neuropathy, nephropathy, osteoarthropathy, etc. [2].

Diabetic arthropathy is a common complication of diabetes and it often occurs, according to literature review in $0.08-13.00 \%$, and in patients with a high risk of glycemic control, it increases to $29 \%$ [3]. Skeleto-muscular lesion appears in children even if the duration of the disease is not long, meantime adult patients have such changes after a much longer disease duration [1]. This happens due to age-related peculiarities of skeleton, gaining bone mass and growth spurt [4]. Decreasing of bone mass leads to disorder of mechanical strength, which causes accelerated bone friability. However, osteopenia in children usually goes covertly and it is not diagnosed throughout a long time [3].

Recently, syndrome of joints movement volume restriction in patients with diabetes is vividly studied, long-existing hyperglycemia takes the leading position in mechanisms of its development, as well as specific complications of this disease [5].

It is known that vitamin $D$ is needed for normal bone mineralization and maintenance of calcium and phosphorus in the blood serum. In the late 80 s, it was found that in osteoblasts and osteocytes there are both vitamin $\mathrm{D}$ receptors (VDR) and $1.25(\mathrm{OH}) 2 \mathrm{D}$ [6]. VD directly participates in bone tissue metabolism, acting with VDR on osteoclasts, chondrocytes, osteoblasts [7]. In addition to the effect of VD on the bone system, the role of VD hypovitaminosis on the pathogenesis of metabolic disorders, including diabetes, is possible [8]. In support of this fact, VDR were found in $\beta$-cells of the pancreas, in adipose tissue and skeletal muscles involved in glucose homeostasis [9].

It is proved that extracellular protein - periostin also takes part in the metabolism of bone tissue. It regulates the collection and adhesion of bone marrow osteoblasts for bone regeneration. An experiment was conducted on mice with lacked periostin. Defects such as stunted growth, short bones, impaired regeneration and bone density were discovered [10]. However, to date, there are only a few works in which the relationship of periostin and vitamin $\mathrm{D}$ and their changes in various pathologies were studied [11]. Nevertheless, until now the question about the whole spectrum of changes in skeleto-muscular system in children with insulin-dependent diabetes is open. That is why there is a strong need for searching of early diagnostic criteria for changes in skeleto-muscular system, especially at early age, when pathological processes can be reversed.
Ключевые слова: Аети, сахарный Аиабет, периостин, витамин D, поАВИжность позвоночника.

Патология. 2020 T. 17, № 1(48).

C. 86-92 


\section{Aim}

To evaluate spine mobility, as an integral marker of joint mobility, according to the duration of the disease and provision of vitamin $\mathrm{D}$ in children with diabetes.

\section{Materials and research methods}

The research was held on the base of Endocrinology Department of Communal Enterprise "Zaporizhzhia regional clinical children hospital" of Zaporizhzhia regional council. Overall, 93 children from 11 to 17 years old with insulin-dependent diabetes were examined. According to the duration of the disease, all children were divided into three groups: the first group consists of 26 children (average age $12.9 \pm 0.4$ years) with the duration of the disease less than a year, the second group consists of 33 patients (average age $13.8 \pm 0.4$ years) with the duration of the disease from one to five years, the third group consists of 34 patients (average age $14.3 \pm 0.4$ years) with the duration of the disease for more than five years. The control group consists of 30 conditionally healthy children that are representative by age and gender.

Evaluation of joints motion was performed in all the children with the help of metrical tests $[12,13]$ :

1) Definition of mobility of cervical region of the spine. 8 centimeters is measured up from VII cervical vertebra, where the mark is made. Then one asks a child to lean head down as much as possible. Then this distance is marked as well. This distance increases for 2-3 centimeters in healthy children.

2) Chin-sternum test. While leaning the head down, a person's chin must touch the sternum. If there is a lesion of cervical region of spine, then some space is left between chin and sternum.

3) Otto test - mobility evaluation of thoracic region of spine. 30 centimeters is measured down from VII cervical vertebra, where the mark is made. Then the distance between these two points is measured, while a child is leaning forward as much as possible. Healthy children have the increase of this distance for 3-4 centimeters.

4) Restriction of chest excursion is used for determination of costovertebral joints mobility. Chest circumference is measured on the level of the IV rib while a child inhales deeply and then exhales. The difference between index of chest circumference is usually 4.0-4.5 centimeters.

5) Schober's test - mobility evaluation of lumbar region of spine. 10 centimeters is measured up from $\mathrm{V}$ lumbar vertebra, where the mark is made. While leaning forward as much as possible this distance increases for 3-4 centimeters.

6) Thomayer test - evaluation of general mobility of the whole spine. It is conducted by measuring distance in centimeters from middle finger of outstretched hands to the floor. This distance equals 0 in healthy children.

The content of vitamin $D$ in blood serum was determined by EIA method using commercial kits: $250 \mathrm{H}$ Vitamin D Total ELISA (DI Asource ImmunoAssays S.A., Belgium).

The group of patients with diabetes mellitus whose vitamin $D$ level was determined consisted of 30 children, the control group consisted of 10 children. During Vitamin $\mathrm{D}$ assessment 5 threshold levels of serum hydroxycal- ciferol concentration were allocated: absolutely toxic level - more than $200 \mathrm{ng} / \mathrm{ml}$; level with a possible manifestation of toxicity - 100-200 ng/ml; adequate level - 30 $100 \mathrm{ng} / \mathrm{ml}$; insufficiency - 21-29 ng/ml and deficiency less than $20 \mathrm{ng} / \mathrm{ml}$ [14].

The group of patients with diabetes mellitus whose periostin level was determined consisted of 62 patients, the control group consisted of 20 patients. The content of periostin in blood serum was determined by EIA method using commercial kits HUMAN PERIOSTIN/OSF-2 ELISA KIT (Aviscera Biosciece Inc., USA)

All the results were analyzed using the set of statistic programs Statistica 13.0 (StatSoft Inc. № JPZ8041382130ARCN10-J). Parametrical methods that helped to evaluate arithmetic mean $(\mathrm{M})$, standard deviation $(\sigma)$ and mean error $(m)$ were applied for normally arranged rates. Check of normality was held with the Shapiro-Wilk test of asymmetry. The method of correlation analysis was used to calculate the Pearson correlation coefficient in the normal distribution of features and the Spearman rank correlation coefficient in their absence. We used the median and quartiles $\mathrm{Me}(\mathrm{Q} 1 ; \mathrm{Q} 2)$ in the case of unequal distribution of features and nonlinear nature of dependence. The significance of the differences in the results obtained for different groups in the normal distribution of characteristics was determined by the parametric (Student's criterion) method. In cases where the distribution law was statistically significantly different from the normal one, the non-parametric Mann-Whitney criterion (U) was calculated as a nonparametric analogue of the Student's criterion. Differences were considered to be significant at $P<0.05$.

In planning this work the bioethical commission gave permission to conduct research. All patients signed informed consent to participate in the study.

All procedures perfomed in studies involving human participants were in accordance with the ethical standards of the institutional and national research committee and with the 1964 Helsinki declaration and its later amendments or comparable ethical standards. Informed consent was obtained from all individual participants included in the study. The full data set by children, their parents, and physician that support the findings of this study are not publicly available due to the ethics approval originally obtained.

\section{Results}

Carried out analyses shows that the longer the duration of diabetes is, the worse functional condition of spine children have (Table 1).

For example, in the group of children who have diabetes for less than a year, there were only solitary cases of decrease of spine functional condition. Moreover, average parameters of spine mobility did not statistically differ from data of control group. Despite that, starting from the second year of disease, it was noticed that there is gradual decrease of mobility of all regions of the spine. The individual analyses showed that patients from the second group suffered primarily from lesion of cervical region of spine, decrease of spine mobility was noticed in one third of patients (Table 2). It was noted 
Table 1. Mobility conditions of spine in children with diabetes, depending on the duration of the disease according to data of metrical tests ( $\mathrm{M} \pm \mathrm{m}$ )

\begin{tabular}{|c|c|c|c|c|}
\hline Metrical tests & I group, $\mathrm{n}=\mathbf{2 6}$ & 2 group, $n=33$ & 3 group, $n=34$ & Control group, $n=30$ \\
\hline Mobility of cervical region of spine, $\mathrm{cm}$ & $2.37 \pm 0.12$ & $1.95 \pm 0.11^{1}$ & $1.65 \pm 0.10^{1,2,3}$ & $2.33 \pm 0.09$ \\
\hline Chin-sternum test, $\mathrm{cm}$ & $0.12 \pm 0.08$ & $0.44 \pm 0.12^{1,2}$ & $0.96 \pm 0.13^{1,2,3}$ & $0.10 \pm 0.07$ \\
\hline Otto test, $\mathrm{cm}$ & $3.25 \pm 0.12$ & $2.91 \pm 0.10$ & $2.68 \pm 0.10^{1,2}$ & $3.13 \pm 0.13$ \\
\hline Schober's test, $\mathrm{cm}$ & $3.42 \pm 0.11$ & $3.17 \pm 0.10^{1}$ & $2.79 \pm 0.10^{1,2,3}$ & $3.53 \pm 0.11$ \\
\hline Chest excursion, $\mathrm{cm}$ & $4.56 \pm 0.13$ & $4.23 \pm 0.15^{1}$ & $3.69 \pm 0.10^{1,2}$ & $4.67 \pm 0.12$ \\
\hline Thomayer test, $\mathrm{cm}$ & $0.15 \pm 0.11$ & $0.82 \pm 0.24^{1,2}$ & $2.68 \pm 0.36^{1,2,3}$ & $0.20 \pm 0.09$ \\
\hline
\end{tabular}

1: a significant $(P<0.05)$ difference compared to the corresponding indicator of the control group; 2: a significant $(P<0.05)$ difference compared to the corresponding indicator of group 1; 3: a significant $(\mathrm{P}<0.05)$ difference compared to the corresponding indicator of group 2 .

Table 2. Registration frequency of spinal movement disorders in children with diabetes, according to metrical tests, depending on duration of the disease $(n, \%)$

\begin{tabular}{|c|c|c|c|c|c|c|c|c|}
\hline \multirow[t]{2}{*}{ Metrical tests } & \multicolumn{2}{|c|}{ I group, $\mathbf{n}=\mathbf{2 6}$} & \multicolumn{2}{|c|}{2 group, $n=33$} & \multicolumn{2}{|c|}{3 group, $n=34$} & \multicolumn{2}{|c|}{ Control group, $n=30$} \\
\hline & $n$ & $\%$ & $\mathrm{n}$ & $\%$ & n & $\%$ & $\mathbf{n}$ & $\%$ \\
\hline Mobility of cervical region of spine, $\mathrm{cm}$ & 2 & 7.7 & 10 & $30.3^{1}$ & 17 & $50.0^{1,2}$ & 2 & 6.6 \\
\hline Chin-sternum test, $\mathrm{cm}$ & 2 & 7.7 & 11 & $33.3^{1,2}$ & 23 & $67.6^{1,2,3}$ & 2 & 6.6 \\
\hline Otto test, $\mathrm{cm}$ & 2 & 7.7 & 8 & $24.2^{2}$ & 16 & $47.1^{1,2,3}$ & 3 & 10.0 \\
\hline Schober's test, cm & 2 & 7.7 & 9 & $27.3^{1,2}$ & 17 & $50.0^{1,2}$ & 1 & 3.3 \\
\hline Chest excursion, $\mathrm{cm}$ & 1 & 3.8 & 4 & 12.1 & 11 & $32.3^{1,2}$ & 1 & 3.3 \\
\hline Thomayer test, $\mathrm{cm}$ & 2 & 7.7 & 11 & $33.3^{1,2}$ & 27 & $79.4^{1,2,3}$ & 2 & 6.6 \\
\hline
\end{tabular}

${ }^{1}$ : a significant $(\mathrm{P}<0.05)$ difference compared to the corresponding indicator of the control group; ${ }^{2}$ : a significant $(\mathrm{P}<0.05)$ difference compared to the corresponding indicator of group $1 ; 3^{3}$ : a significant $(\mathrm{P}<0.05)$ difference compared to the corresponding indicator of group 2 .

Table 3. Mobility conditions of spine in children with diabetes, according to the status of glycaemic control $(\mathrm{M} \pm \mathrm{m})$

\begin{tabular}{|c|c|c|c|c|}
\hline \multirow[t]{2}{*}{ Metrical tests } & \multicolumn{3}{|l|}{ Glycemic control } & \multirow[t]{2}{*}{ Control group, $n=3 c$} \\
\hline & Ideal and optimal, $\mathrm{n}=\mathbf{2 0}$ & Suboptimal, $n=29$ & High risk to life, $n=44$ & \\
\hline Mobility of cervical region of spine, $\mathrm{cm}$ & $2.28 \pm 0.10$ & $2.18 \pm 0.10$ & $1.74 \pm 0.08^{1,2,3}$ & $2.33 \pm 0.09$ \\
\hline Chin-sternum test, $\mathrm{cm}$ & $0.08 \pm 0.06$ & $0.32 \pm 0.09^{1,2}$ & $0.63 \pm 0.09^{1,2,3}$ & $0.10 \pm 0.07$ \\
\hline Otto test, $\mathrm{cm}$ & $3.11 \pm 0.14$ & $2.92 \pm 0.11$ & $2.80 \pm 0.10$ & $3.13 \pm 0.13$ \\
\hline Schober's test, $\mathrm{cm}$ & $3.42 \pm 0.11$ & $3.25 \pm 0.10^{1}$ & $2.98 \pm 0.08^{1,2,3}$ & $3.53 \pm 0.11$ \\
\hline Chest excursion, $\mathrm{cm}$ & $4.56 \pm 0.13$ & $4.17 \pm 0.12^{1}$ & $4.03 \pm 0.10^{1,2}$ & $4.67 \pm 0.12$ \\
\hline Thomayer test, $\mathrm{cm}$ & $0.76 \pm 0.21$ & $1.90 \pm 0.43^{1,2}$ & $3.48 \pm 0.56^{1,2,3}$ & $0.20 \pm 0.09$ \\
\hline
\end{tabular}

1: a significant $(P<0.05)$ difference compared to the corresponding indicator of the control group; ${ }^{2}$ : a significant $(P<0.05)$ difference compared to the corresponding indicator of group with ideal and optimal glycemic control; ${ }^{3}$ : a significant $(P<0.05)$ difference compared to the corresponding indicator of group with suboptimal glycemic control.

Table 4. The amount of vitamin $D$ and periostin in blood serum of children with diabetes according to the duration of the disease (Me (Q25-Q75))

\begin{tabular}{|c|c|c|c|c|}
\hline Score & 1 group & 2 group & 3 group & Control group \\
\hline Vitamin D, ng/ml & $\begin{array}{l}32(30-35) \\
n=10\end{array}$ & $\begin{array}{l}29(28-34) \\
n=10\end{array}$ & $\begin{array}{l}29.5(29-31) \\
n=10\end{array}$ & $\begin{array}{l}31,5(30-33) \\
\mathrm{n}=10\end{array}$ \\
\hline Periostin, ng/ml & $\begin{array}{l}37.2(22.7-114.7)^{1} \\
n=20\end{array}$ & $\begin{array}{l}44(18-145)^{1} \\
n=21\end{array}$ & $\begin{array}{l}60(38.5-128.0)^{1,2} \\
n=21\end{array}$ & $\begin{array}{l}2.5(1.3-33.5) \\
n=20\end{array}$ \\
\hline
\end{tabular}

${ }^{1}$ : a significant $(P<0.01)$ difference compared to the corresponding indicator of the control group; ${ }^{2}$ : a significant $(P<0.05)$ difference compared to the corresponding indicator of group 1.

that the same number of patients in this group had mobility impairment of spine, which was revealed during Thomayer's test (Table 2).

We got the worst results in patients from the third group, all their indicators that characterize parameters of functional condition of spine, significantly differ from the same parameters of patients in control group, as well as from patients' indicators from the first and second groups.

Data analyses, which is given in Fig. 3, has showed that if the duration of diabetes is more than five years, then there is a decrease of movements amplitude of cervical region of spine in the majority of patients $(67.6 \%)$. It has been revealed during carrying out chin-sternum test, which is 8.7 times more often than in patients with 1-year duration of diabetes and 2 times more often comparing to indicators of patients from the second group $(P<0.05)$.
We noticed significant decrease of mobility of thoracic and lumbar regions of spine in patients from the third group comparing to other researched groups $(P<0.05)$. Registered changes were reflected in general spine mobility, and its restriction was noticed in 27 (79.4\%) patients from the third group.

Considering impact of hyperglycemia on the development of diabetic arthropathy we analyzed the spine mobility in children with diabetes, according to the status of glycaemic control (Table 3).

The analysis showed that there was no violation of the state of spinal mobility with ideal and optimal glycemic control in patients with diabetes. At the same time lack of compensation for the disease was accompanied by decrease of mobility of all regions of the spine. The most significant deviations from normative indicators were determined in patients with glycemic control with a high 


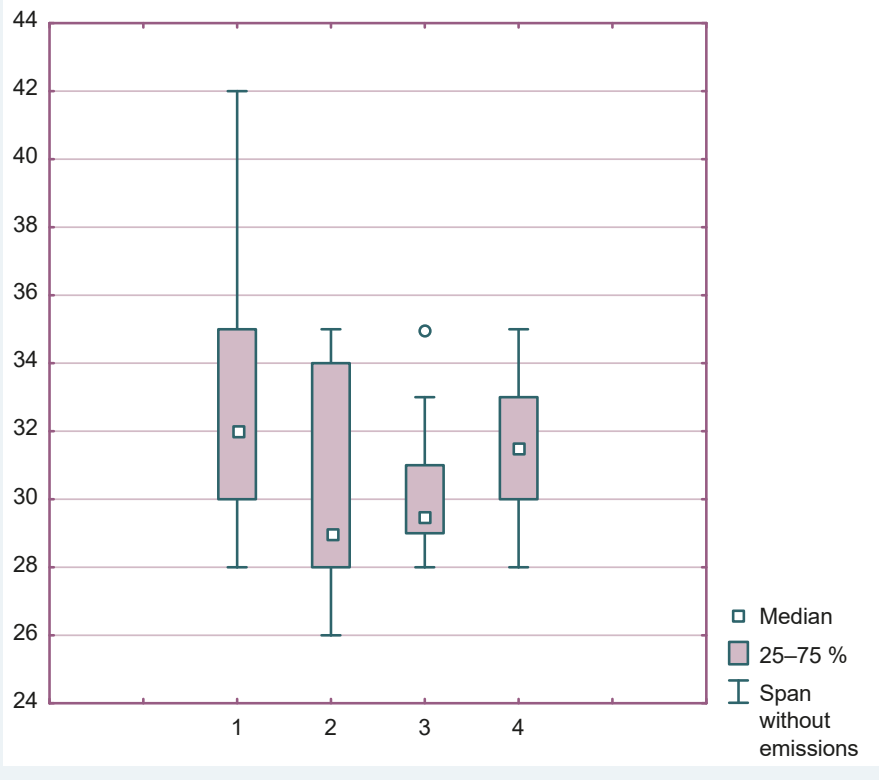

Fig. 1. Diagram of variation of vitamin $D$ amount in blood serum of children with diabetes according to the disease duration.

1: group 1; 2: group 2; 3: group 3; 4: control group.

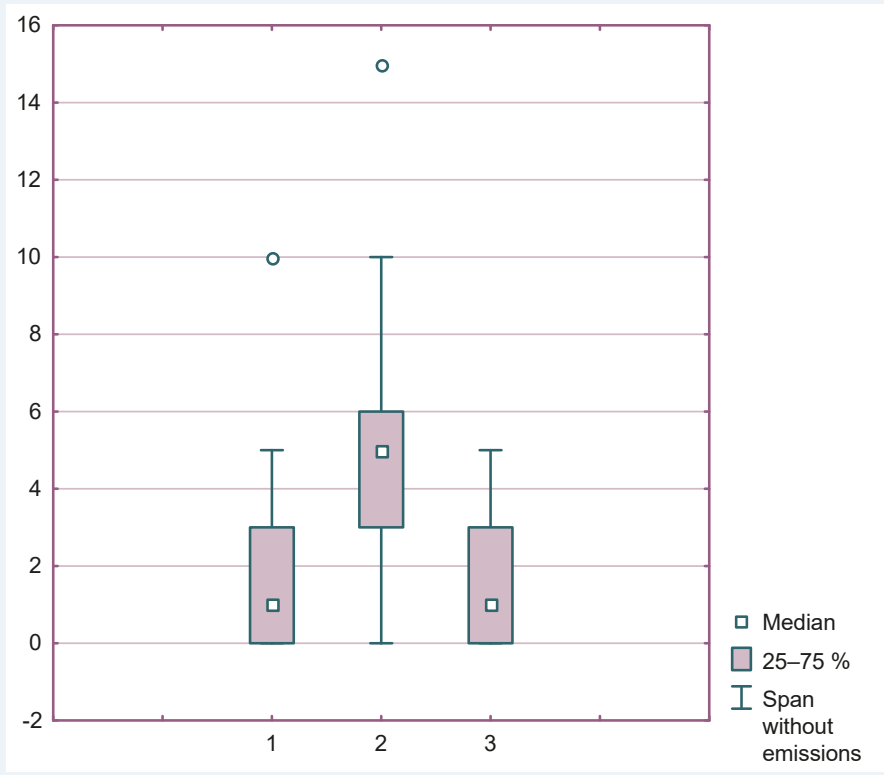

Fig. 2. Variation diagram of the Thomayer test values, depending on the availability of vitamin $D$ in children with diabetes according to the duration of a disease.

1: patients with normal vitamin D levels; 2: patients with deficient levels of vitamin $D ; 3$ : control group.

risk for life. In these children, total spine mobility was reduced by 17.6 times compared with the control group $(P<0.01)$ and by 4.6 times compared to patients with good compensation for diabetes $(P<0.05)$.

Vitamin $\mathrm{D}$ and periostin affect bone tissue. We have studied the amount of vitamin $D$ and periostin in the blood serum of children with diabetes according to the duration of the disease (Table 4).

The analysis of vitamin $D$ deficiency showed lack of significant difference in vitamin $\mathrm{D}$ provision between children with diabetes and the control group $(P>0.05)$.
We observed a decrease in blood serum vitamin D levels, which is progressing with the increase of illness duration. The variation diagram of vitamin $\mathrm{D}$ amount in blood serum in investigated groups is given in Fig. 1.

As it is shown in Fig. 1, there was wide variation in levels of vitamin D $(26.0-42.0 \mathrm{ng} / \mathrm{ml})$ in blood serum of children with diabetes. The highest variability in the content of vitamin $D$ in the blood serum was detected in the group of patients with a duration of diabetes up to 1 year, concentration fluctuated within $28.0-42.0 \mathrm{ng} / \mathrm{ml}$. The range of $25(\mathrm{OH}) \mathrm{D}$ values of the control group was $28.0-35.0 \mathrm{ng} / \mathrm{ml}$. The individual analyses showed that in the first year of the disease, vitamin $D$ deficiency was only $10 \%$. At that time, in group 2 in $50 \%$ of children, and in group 3 in $80 \%$ of children there was a decrease in vitamin $\mathrm{D}$ level $(\mathrm{P}<0.05)$.

We have analyzed the relationship between the state of general spinal mobility and the level of vitamin D provision (Fig. 2). As a result, the data obtained showed that in children with diabetes mellitus, an insufficient level of vitamin $\mathrm{D}$ provision was accompanied by a deterioration in the state of general spinal mobility (Fig. 2).

As shown in Fig. 2, in patients whose vitamin D content was in the range of $30-100 \mathrm{ng} / \mathrm{ml}$, the Thomayer test did not differ from the data obtained in the children of the control group, and was $1.0[0.0 ; 3.0] \mathrm{cm}(P>0.05)$ in both groups. At the same time, children who were found to be deficient in vitamin $\mathrm{D}$ had a worsening of the overall mobility of the spine and showed a statistically significant increase in the Thomayer test to $5.0[3.0 ; 6.0] \mathrm{cm}$ $(P<0.05)$. Thus, the total mobility of the spine depended on the level of vitamin $D$, which was confirmed by the inverse correlation between its content in the serum and Thomayer test $(r=-0.38, P<0.05)$. There was an inverse correlation between the content of vitamin $D$ in the blood serum and glycated hemoglobin $(r=-0.41, P<0.05)$. Low values of vitamin $D$ were inherent in children with glycemic control with a high risk for life.

The next stage of our work was the study of the content of periostin in the blood serum of children with diabetes mellitus (Table 4). Analysis of the data showed that the level of periostin in the blood serum of children with diabetes mellitus had a wide variation of values (8.0-225.0 $\mathrm{ng} / \mathrm{ml})$, but was statistically higher than its level in the control group $(P<0.05)$ regardless of the duration of the disease. It was conduct data analysis of the serum periostin content in patients with diabetes mellitus depending on the duration of the disease. A gradual increase with the progression of diabetes with the highest values in children with longer duration of diabetes was established (Fig. 3).

Given that both vitamin D and periostin are involved in bone metabolism [15], we examined the content of the latter in children with diabetes mellitus, depending on the level of vitamin D provision (Fig. 4).

Visual analysis diagram of variation showed that children with low vitamin $D$ supply had high serum periostin content and it was 140.00 [45.75; 177.75$] \mathrm{ng} / \mathrm{ml}$. At the same time, in children with diabetes with normal supply of vitamin $\mathrm{D}$, the median concentration of serum periostin was $44.0[27.0 ; 64.0] \mathrm{ng} / \mathrm{ml}(\mathrm{P}<0.05)$. However, it did not reach the control values $(2.5[1.3 ; 33.5] \mathrm{ng} / \mathrm{ml}, \mathrm{P}<0.05)$. 
The obtained data were confirmed by the inverse correlation relationship of medium strength $(r=-0.36, P<0.05)$ between the level of periostin and the vitamin $D$ content in the blood serum of children with diabetes mellitus.

\section{Discussion}

All data obtained has shown that a violation of the functional capabilities of the spine was observed, which was manifested by a decrease in mobility in all its regions in children with diabetes. The revealed changes were progressing in the dynamics of the disease and occurred against the background of lack of diabetes compensation, insufficiency of vitamin $D$ and an increase in blood serum periostin.

It is known that bone is a dynamic system in which the remodeling processes continuously occur: formation and resorption of bone tissue. Provision of vitamin D influences the process of resorption. In case of insufficiency or deficiency of vitamin $D$ there is a violation of bone homeostasis. In addition, it is believed that vitamin $D$ affects glucose homeostasis by acting directly on $\beta$-cells and indirectly through calcium regulation, since insulin secretion depends on calcium [16]. Our findings also indicate an existing relationship between vitamin $\mathrm{D}$ and the state of glycemic control in patients with diabetes. Our findings are consistent with other studies, which demonstrated a significant improvement in glycemic control in the treatment of vitamin $D$ deficiency in children and teenagers with diabetes [17].

Another marker of bone metabolism is periostin. It is expressed in bone by osteocytes and plays a key role in the regulation of osteoblast function and bone formation [15]. Our results show that periostin can be a marker of changes in the osteoarticular system and can be used as a diagnostic tool in the development of diabetic arthropathy. The results of our study show that one of the mechanisms for increasing level of periostin in diabetes mellitus is lack of vitamin $\mathrm{D}$. Together, this leads to a violation of the functional state of the joints, in particular the spine.

\section{Conclusions}

1. Children with diabetes are characterized by a deterioration in the functional state of the spine in the form of reduced mobility in all its regions, which progresses with an increase in the disease duration. One of the mechanisms for the development of the revealed violations is poor compensation for diabetes and vitamin $\mathrm{D}$ deficiency.

2. The results of our study prove that it is necessary to determine the level of vitamin $D$ in children with diabetes mellitus. It requires timely correction of the deficit in order to improve glycemic control and the prevention of violations of the bones and joints.

Prospects for further research. In the future, it is planned to study the condition of the joints of the upper and lower limbs in children with diabetes mellitus, and to determine the pathogenetic factors that influence the development of their changes.

\section{Funding}

The dissertation is planned to be carried out as part of the research work of the Department of Hospital Pediatrics

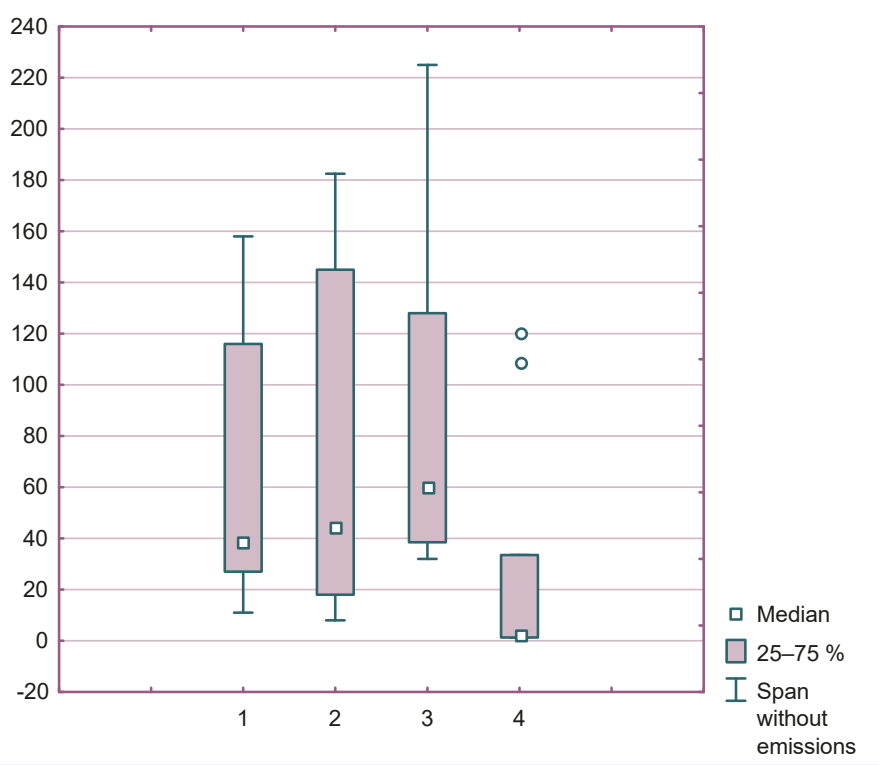

Fig. 3. Variation diagram of periostin amount in blood serum of children with diabetes according to the duration of the disease.

1: group 1; 2: group 2; 3: group 3; 4: control group.

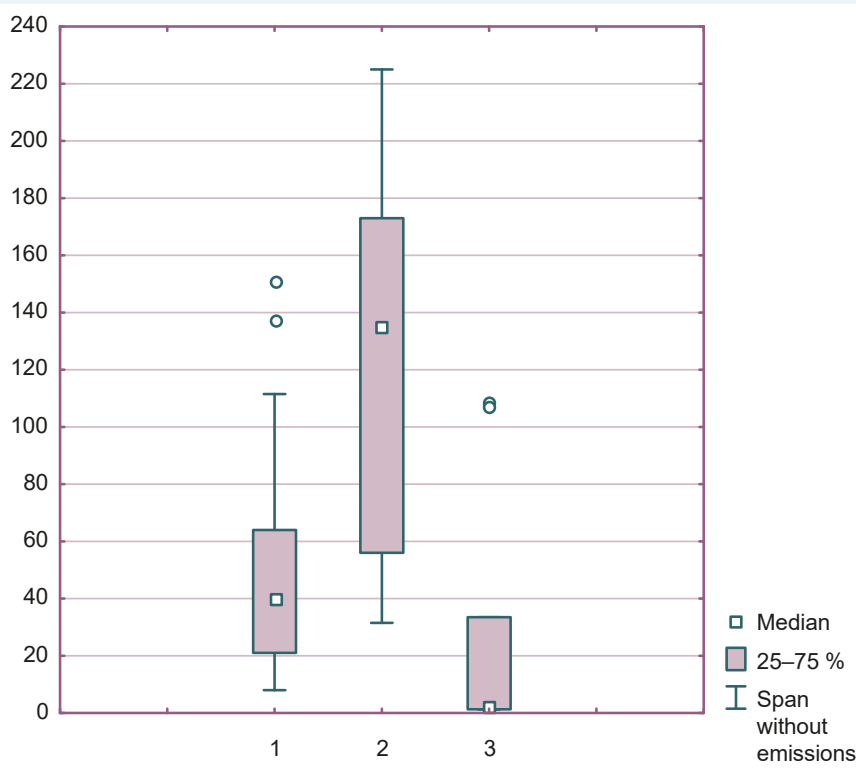

Fig. 4. Variation diagram of periostin amount in blood serum of kids with diabetes according to the availability of vitamin $D$.

1: patients with normal vitamin D levels; 2: patients with deficient levels of vitamin D; 3: control group.

of Zaporizhzhia State Medical University: "Prediction of the occurrence, diagnosis and treatment of the disorders of musculoskeletal system in children with diabetes" (№ 0119U100456).

Conflicts of interest: authors have no conflict of interest to declare. Конфмікт інтересів: віАсутній. 
Information about authors:

Pashkova O. Ye., MD, PhD, DSc, Professor of the Department of Hospital Pediatrics, Zaporizhzhia State Medical University, Ukraine.

Lysenko K. P., PhD Student of the Department of Hospital Pediatrics, Zaporizhzhia State Medical University, Ukraine.

\section{Відомості про авторів:}

Пашкова О. Є., А-р меА. наук, професор каф. госпітальної педіатрії, Запорізький Аержавний медичний університет, Україна.

^исенко К. П., PhD аспірант каф. госпітальної педіатрії, Запорізький Аержавний меАичний університет, Україна.

\section{Сведения об авторах:}

Пашкова Е. Е., А-р меА. наук, профессор каф. госпитальной педиатрии, Запоржский государственный медицинский университет, Украина.

Аысенко К. П., PhD аспирант каф. госпитальной педиатрии, Запоржский государственный медицинский университет, Украина.

\section{References}

[1] Al-Hariri, M. (2016). Sweet Bones: The Pathogenesis of Bone Alteration in Diabetes. Journal of Diabetes Research, 2016, Article 6969040. https://doi.org/10.1155/2016/6969040

[2] Schacter, G. I., \& Leslie, W. D. (2017). Diabetes and Bone Disease. Endocrinology and Metabolism Clinics of North America, 46(1), 63-85. https://doi.org/10.1016/j.ecl.2016.09.010

[3] Zhao, H. M., Diao, J. Y. Liang, X. J., Zhang, F. \& Hao, D. J. (2017) Pathogenesis and potential relative risk factors of diabetic neuropathic osteoarthropathy. Journal of Orthopaedic Surgery and Research, 12, Article 142. htpp://doi.org/10.1186/s13018-017-0634-8

[4] Maltsev, S. V., Mansurova, G. Sh., Kolesnichenko, T. V., \& Zotov, N. A. (2013). Mineral'naya plotnost' kosti u detei v raznye vozrastnye periody [Bone mineral density in children in different age periods]. Prakticheskaya meditsina, (6), 106-108. [in Russian].

[5] Schvets, N. I., \& Bentsa, T. M. (2011). Diabeticheskaya osteoartropatiya: diagnostika i lechenie (Obzor literatury) [Diabetic osteoarthropathy: diagnostic and treatment (iiterature review)]. Suchasni aspekty viiskovoi medytsyny, (18), 417-422. [in Russian].

[6] Boivin, G., Mesguich, P., Pike, J. W., Bouillon, R., Meunier, P. J., Haussler, M. R., Dubois, P. M., \& Morel, G. (1987). Ultrastructural immunocytochemical localization of endogenous 1,25 -dihydroxyvitamin-d3 and its receptors in osteoblasts and osteocytes from neonatal mouse and rat calvaria. Bone and Mineral, 3(2), 125-136.

[7] Sorensen, I. M., Joner, G., Jenum, P. A., Eskild, A., Brunborg, C., Torjesen, P. A., \& Stene, L. C. (2016). Vitamin D-binding protein and 25-hydroxyvitamin $D$ during pregnancy in mothers whose children later developed type 1 diabetes. Diabetes-Metabolism Research and Reviews, 32(8), 883-890. https://doi.org/10.1002/dmrr.2812

[8] Giustina, A, \& Bilezikian, J. P. (Eds.). (2018). Vitamin D in Clinical Medicine (Vol. 50, pp. 1-8). Karger: Basal, Switzerland. https://doi. org/10.1159/000486733

[9] Egshatyan, L. V. (2018). Neklassicheskie effekty vitamina D [Non-classical effects of vitamin D]. Ozhirenie i metabolizm, 15(1), 12-18. [in Russian]. https://doi.org/10.14341/omet2018112-18

[10] Yan, J., Liu, H. J., Li, H., Chen, L., Bian, Y. Q., Zhao, B., Han, H. X., Han, S. Z., Han, L. R., Wang, D. W., \& Yang, X. F. (2017). Circulating periostin levels increase in association with bone density loss and healing progression during the early phase of hip fracture in Chinese older women. Osteoporosis International, 28(8), 2335-2341. https:/l doi.org/10.1007/s00198-017-4034-z

[11] Povorozniuk, V. V., Pludovski, P., Balatska, N. I., Muts, V. Ya., \& Klymovytskyi, F. V. (2014). Defitsyt ta nedostatnist vitaminu D: epidemiolohiia, diahnostyka, profilaktyka ta likuvannia [Deficit and deficiency Vitamin D: epidemiology, diagnosis, prevention and treatment]. Donetsk : Zaslavskyi O. Yu. [in Ukrainian].

[12] Aksenova, T. A., Tsarenok, S. Yu., Ivashchenko, N. F., Panina, E. S., Makkaveeva, O. N., \& Tereshkov, M. P. (2016). Sovremennye metody diagnostiki ankiloziruyushchego spondiloartrita [Modern methods for the diagnosis of ankylosing spondylitis]. Zabaikalskii meditsinskii zhurnal, (1), 11-18. [in Russian].

[13] Raevsky, R. T. \& Kanishevskii, S. M. (1985). Professionalno-prikladnaya fizicheskaya podgotovka studentov vysshikh uchebnykh zavedenii [Professional and Applied Training of Students of Technical Universities: Training. allowance]. Moscow: Higher school. [in Russian].

[14] Pludowski, P., Karczmarewicz, E., Bayer, M., Carter, G., Chlebna-Sokol, D., ... Zmijewski, M. A. (2013). Practical guidelines for the supplementation of vitamin $D$ and the treatment of deficits in Central Europe - recommended vitamin D intakes in the general population and groups at risk of vitamin D deficiency. Endokrynologia Polska, 64(4), 319-327. https://doi.org/10.5603/ep.2013.0012

[15] Idolazzi, L., Ridolo, E., Fassio, A., Gatti, D., Montagni, M., Caminati, M., Martignago, I., Incorvaia, C., \& Senna, G. (2017). Periostin: The bone and beyond. European Journal of Internal Medicine, 38, 12-16. https:// doi.org/10.1016/j.ejim.2016.11.015

[16] Savastio, S., Cadario, F., Genoni, G., Bellomo, G., Bagnati, M., Secco, G., Picchi, R., Giglione, E., \& Bona, G. (2016). Vitamin D Deficiency and Glycemic Status in Children and Adolescents with Type 1 Diabetes Mellitus. Plos One, 11(9), Article e0162554. https://doi.org/10.1371/ journal.pone. 0162554

[17] Giri, D., Pintus, D., Burnside, G., Ghatak, A., Mehta, F., Paul, P., \& Senniappan, S. (2017). Treating vitamin D deficiency in children with type i diabetes could improve their glycaemic control. BMC Research Notes, 10(1). https://doi.org/10.1186/s13104-017-2794-3 